\title{
Treatment of taeniasis and cysticercosis with praziquantel and albendazole
}

\author{
Abdulbar Hamid $^{f}$, Sri S. Margono ${ }^{*}$, Toni Wandra ${ }^{\S}$, Akira Ito ${ }^{\#}$
}

\begin{abstract}
Abstrak
Metode mutakhir, dosis dan hasil pengobatan medik taeniasis/sistiserkosis, penyakit zoo-parasitik yang disebabkan Taenia solium dan Taenia saginata dibahas. Pada kasus sistiserkosis T. solium, khususnya neurosistiserkosis waktu optimal dan dosis untuk sistiserkosis dengan albendazol adalah selama 8 hari, $15 \mathrm{mg} / \mathrm{kg} / \mathrm{hari}$ dibagi untuk dua kali sehari ditambah prednison $50 \mathrm{mg} / \mathrm{hari}$ pada pagi hari. Obat ini efektif terhadap parasit di hampir semua lokasi sebanyak yaitu 80-90\% terhadap kista yang makroskopik tampak dengan cara imaging. Untuk taeniasis dosis tunggal prazikuantel, 10-15 mg/kg memberi hasil angka penyembuhan lebih dari 90\%. Efek samping ringan seperti nausea, sakit kepala dan perut dapat ditemulan. Evaluasi terapi dengan obat dilakukan berdasarkan evaluasi klinik, radiologi dan serologi. Di Papua (=Irian Jaya) sembilan kasus dengan diagnosis kemungkinan neurosistiserkosis, sero-positif, telah diterapi dengan albendazol, $1200 \mathrm{mg}$ dosis tunggal selama 15 hari. Ditambah dengan prednison, tiga kali sehari 1 tablet, $5 \mathrm{mg}$ selama 7 hari. Setelah setahun 6 kasus masih tetap sero-positif. Pada waktu yang sama prazikuantel, 1200 mg, dosis tunggal diberikan kepada sepuluh pasien selama 15 hari dengan prednison, 3 kali sehari 1 tablet, 5 mg selama 7 hari. Setelah setahun 5 kasus masih tetap sero-positif. Kedua-duanya, albendazol dan prazikuantel, adalah obat yang efektif terhadap taeniasis dan sistiserkosis dengan efek samping ringan. Terapi simptomatik diberikan bilamana dianggap perlu. (Med J Indones 2005; 14:253-7)
\end{abstract}

\begin{abstract}
Recent methods, doses and results of medical treatment on taeniasis/cysticercosis, a zoo-notic parasitic disease caused by Taenia solium and Taenia saginata are discussed. In cases of cysticercosis T. solium, especially neurocysticercosis the optimal length and dose of albendazole is a course of 8 days with doses of $15 \mathrm{mg} / \mathrm{kg} /$ day divided in two times added by $50 \mathrm{mg} /$ day of prednisone in the morning. The drug is effective in almost any location of the parasites for 80-90\% of macroscopic cysts seen by imaging studies. For taeniasis a single dose of praziquantel, $10-15 \mathrm{mg} / \mathrm{kg}$ achieves cure rates of more than $90 \%$. Side effects such as nausea, headache and abdominal pain are mild. Evaluation of drug treatment is done by clinical, radiological and serological evaluation. In Papua (=Irian Jaya) nine cases with suspected neurocysticercosis, serologically positive, were treated with $1200 \mathrm{mg}$ single dose albendazole for 15 days. Prednisone tablets, three times daily one tablet, $5 \mathrm{mg}$ during 7 days were added. After one year 6 cases were still serologic positive. At the same time praziquantel, $1200 \mathrm{mg}$, single dose was given to ten cases during 15 days and prednisone tablets, 3 times daily one tablet, $5 \mathrm{mg}$ during 7 days. After one year 5 sero-positive cases were still found. Albendazole and praziquantel are both effective drugs for taeniasis and cysticercosis, with minor side effects. In addition symptomatic treatment should be given if necessary. (Med J Indones 2005; 14:253-7)
\end{abstract}

Keywords: albendazol, praziquantel, cysticercosis, taeniasis

Two tapeworms, Taenia saginata and Taenia solium are frequently infecting humans in several parts of the world. The adult worm causes intestinal taeniasis in

\footnotetext{
* Directorate Research and Community Service, University of Indonesia, Jakarta, Indonesia

${ }^{f}$ Department of Neurology, Faculty of Medicine, University of Indonesia, Jakarta, Indonesia

${ }^{\S}$ Directorate General of Communicable Disease Control and Environmental Health, Ministry of Health, Jakarta, Indonesia

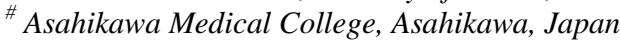

humans whereas the larval stage of $T$. solium is responsible in causing a disease called cysticercercosis. The most severe clinical picture is due to the invading larva of T. solium into the human brain with neurological signs and symptoms as consequences.

The disease is mostly prevalent in Latin America, Asia and Africa, especially in developing countries in which low sanitary habits and socioeconomic conditions perpetuate its dissemination. In Indonesia the disease is known to exist in several provinces i.e. Bali, North Sumatra, Papua, East Nusa Tenggara, Lampung, North Sulawesi, Sulawesi Tenggara and West Kalimantan. 
Besides the eight provinces the disease is also found in areas with resettled inhabitants from endemic areas. ${ }^{1}$

It should be mentioned that in Samosir Island, North Sumatra tapeworms in humans early identified as Taenia saginata are now known as Taenia asiatica. Morphologically the worms are similar with Taenia saginata however the larval stage is found in organs, usually liver of pigs, contrarily with Taenia saginata, which used cattle as the intermediate host. ${ }^{2,3}$

All this time, referring to Indonesia chemical treatment of taeniasis and cysticercosis is not always simple because modern drugs are not easily available on the market and health workers are not always familiar with the standard treatment. Therefore it is useful to elaborate in this article on the chemical treatment of the disease, especially with praziquantel and albendazole, two effective drugs.

\section{CLINICAL PICTURE OF TAENIASIS AND CYSTICERCOSIS}

\section{Taeniasis}

Nearly no signs or symptoms are found in patients suffering from taeniasis. Mild gastrointestinal complaints are sometimes acknowledged such as nausea, headache, abdominal discomfort, diarrhea, hunger. In cases of taeniasis caused by $T$. saginata segments, called proglottids are actively crawling out of the anus and sometimes embarrassed the patient if drop in public places.

\section{Cysticercosis}

Symptoms due to cysts invading the central system depend on the location of cysts, the number of cysts and the immune response of the patient to the parasite. We have the 1) parenchymal neurocysticercosis with symptoms including seizures, focal neurologic symptoms due to mass effect from the cyst or its accompanying edema or intellectual deterioration. Sometimes increased intracranial pressure is present, 2) a severe form of parenchymal cysticercosis is cysticercal encephalitis, a disease resulting from an acute immune / inflammatory response with severe edema in patients invaded with numerous cysts 3) hydrocephalus can be caused by intraventricular obstruction or due to impairment of spinal fluid absorption secondary to meningeal inflammation. Ocular cysticercosis should be managed carefully in the hospital. ${ }^{4,5}$ Besides neurocysticercosis subcutaneous cysticercosis is a disease entity often found in several parts of the world, including Indonesia. However, contrarily to cases with neurocysticercosis cases with subcutaneous cysticercosis have no many complaints except for cosmetic reasons.

\section{Chemical treatment}

Although there were controversies in using cysticidal drugs in general it is now accepted to use the drugs for patients with viable cysts. Especially in neurocysticercosis the simultaneous therapy with cysticidal drugs and its accompanying inflammation, allows the treatment of the great majority of patients at the outpatient clinic, reserving hospitalization only for those cases with a large number of cysts or with cysts in dangerous sites such as the brain stem, the optic nerve etc.

\section{PRAZIQUANTEL AND ALBENDAZOLE}

\section{Taeniasis}

A total of 24 patients in North Sumatra Province and 54 patients in Bali Province were treated for taeniasis saginata as well as taeniasis solium with praziquantel, $10 \mathrm{mg} / \mathrm{kg} /$ body weight. ${ }^{6}$ The cure rate in North Sumatra was $87.5 \%$ and in Bali $70.37 \%$ without significant side effects. Stool examinations for eggs and proglottids were negative one and three months after treatment. In the same area 35 patients were treated with atabrin or praziquantel and afterwards 34 expelled T. saginata and 1 T.solium. ${ }^{2}$

Praziquantel in a single dose of $10 \mathrm{mg} / \mathrm{kg}$ achieves cure rates of about $99 \%$ in taeniasis saginata. ${ }^{8} \mathrm{~A}$ rather fatty meal in the evening before administration of the drug is recommended. Pre- and post-treatment purges are not used. At present, treatment in Indonesia consists of a single dose of $10-20 \mathrm{mg} / \mathrm{kg} / \mathrm{body}$ weight, usually 1-2 tablets of $600 \mathrm{mg}$ praziquantel, which are distributed to individuals complaining of expelling proglottids in stools. ${ }^{1,9}$ After that purging with $30 \mathrm{~g}$ of magnesium sulfate is still the standard practice, which is said to be unnecessary, especially in cases of taeniasis saginata. 


\section{Cysticercosis}

Praziquantel is a pyrazinoquinoline compound effective against a broad range of trematodes and cestodes. ${ }^{10,11}$ Treatment of cysticercosis, especially neurocysticercosis depends on location, symptoms such as seizures or hydrocephalus, the viability of the cysts and the degree of host inflammatory response. Patients with inactive infection with seizures and calcifications on neuroimaging are thought not to harbor viable parasites and therefore in such cases treatment should be symptomatic with anticonvulsants for the seizures. ${ }^{12}$

In cases of neurocysticercosis recent studies showed that the optimal length and dose of albendazole was a course of 8 days with doses of $15 \mathrm{mg} / \mathrm{kg} / \mathrm{day}$ divided in two times, added by $50 \mathrm{mg} /$ day of prednisone each morning. The dose with this schedule eliminates between $80-90 \%$ of macroscopic cysts seen by imaging studies. The drug is effective in almost any location of the parasites: muscle cysticeri, brain parenchymal cysticerci, giant subarachnoid cysts, ventricular cysts and subretinal cysticercus. ${ }^{13-18}$

In Jakarta a case was recorded of a Balinese woman treated with albendazole and later on with praziquantel. The female patient, 33 year old, with multiple cysts was given albendazole, $15 \mathrm{mg} / \mathrm{kg}$ body weight, as a single dose for 10 days. At the same time a single dose of methyl prednisolone, $750 \mathrm{mg}$ was injected intra-venous. Afterwards for the prevention of seizures carbamazepine was used one tablet, twice a day. A positive copro-antigen test indicated the presence of an adult worm and a single dose of 1050 mg praziquantel was given, followed by purging with 30 gram magnesium sulfate solution, however segments of the worm could not be found in stools collected during three times 24 hours. ${ }^{19}$

Considering praziquantel, a new approach is recommended, consisting of a single daily dose of 75 $\mathrm{mg} / \mathrm{kg}$ divided in three doses of $25 \mathrm{mg} / \mathrm{kg}$ administered at 7 am, 9 am and 11 am accompanied by $400 \mathrm{mg}$ of cimetidine in order to increase the praziquantel level in the plasma with each dose. Between 70-80 \% of macroscopic cysts are eliminated with this schedule. Consuming regular meals during treatment improves again plasma levels of praziquantel. The inflammatory reaction produced by the sudden destruction of cysticerci, should be eliminated by administering $50 \mathrm{mg}$ of prednisone, three hours after the last dose, during 3 or 4 continuous days. For subarachnoid, ventricular and ocular cysticercosis praziquantel is less effective than albendazole. $^{14,20}$

\section{Comparison of albendazole to praziquantel}

In Brazil, Takayanagui and $\operatorname{Jardim}^{15}$ treated intraparenchymal brain cysticercosis in one group of 22 patients with praziquantel and in a second group of 21 patients with albendazole. In addition 16 patients were treated with symptomatic drugs only and used as controls. Praziquantel was given at daily doses of 50 $\mathrm{mg} / \mathrm{kg}$ body weight for 21 days whereas patients were treated with daily doses of $20 \mathrm{mg} / \mathrm{kg}$ body weight with albendazole also for 21 days. Because of side effects in two patients receiving praziquantel and one patient receiving albendazole treatment was discontinued. There was an increased intra-cranial pressure and one of them died. Both groups received dexamethasone sodium phosphate at daily doses of 6 $\mathrm{mg}$. Anticonvulsant medication was continued. Among the 20 patients receiving full treatment with praziquantel a $50 \%$ reduction of the total number of lesions were detected by CT scans six months after treatment. Three patients showed total disappearance of the cysts. During treatment 17 patients (85\%) suffered from adverse effects such as headache, vomiting, dizziness or seizures. Full treatment of 20 patients with albendazole showed a decrease of $88 \%$ of the total lesions. Total disappearance of lesions were found in $11(55 \%)$ of the patients. Adverse reactions were similar to those during treatment with praziquantel. Although both drugs were effectivive, it was concluded that analysis of the clinical course showed a high frequency of neurologic sequelae. ${ }^{15}$

In an attempt to obtain an effective dose and schedule a group of 62 individuals diagnosed as suspected neurocysticercosis were treated with albendazole or praziquantel. Thirty-three were treated with albendazole, $1200 \mathrm{mg}$ single dose during 15 days whereas 29 cases were given praziquantel, $1200 \mathrm{mg}$ single dose for 15 days. In addition both groups were given prednisone tablets, 3 times a day one tablet of $5 \mathrm{mg}$ during 7 days. Treatment of 3 cases treated with albendazole and 7 cases with praziquantel was not completed because of side effects. Only 9 among the 33 cases treated with albendazole and 10 among 29 praziquantel cases could be evaluated after one year. After one year 6 cases treated with albendazole and 5 cases with praziquantel were still sero-positive. The diagnosis was established by history of illness, physical and neurological as well as serological examinations by immunoblot as described by Ito et al. (1998). ${ }^{20}$ No 
electro-encephalogram (EEG) or neuro-imaging could be done in this area. ${ }^{9}$

\section{Other drugs}

Another effective drug, especially for taeniasis however at present not available in Indonesia, is niclosamide. A cure rate of over $90 \%$ is expected if given as a single dose of four tablets $(2 \mathrm{~g})$. It should be administered in the morning before breakfast, chewed thoroughly and swallowed with water. After two hours the patient is permitted to consume food. In most cases no side effects are observed. ${ }^{6}$ It is not necessary to use pre- or post-treatment purges. ${ }^{8}$

\section{DISCUSSION AND CONCLUSION}

\section{Taeniasis}

For taeniasis, caused by Taenia solium and Taenia saginata, as well as Taenia asiatica the drug of choice is praziquantel, $10-20 \mathrm{mg}$ single dose, which has a cure rate of $90 \%$ or more. The drug, a pyrazinoisoquinoline derivative, is absorbed by the adult worm as praziquantel and at low effective dose caused paralyses and spasm of the adult worm. At higher effective dose vacuolization and vesiculation of the tegument of the worm occurred; therefore it is a vermicide. After using the drug the patient is somewhat drowsy and his or her mental alertness is decreased. ${ }^{8}$ Treatment schedule which we used is as follows: the day before drug administration no meal or a light meal should be consumed; next day the patient should come after fasting or after a light meal, praziquantel is then given, followed by 30 gram magnesium sulfate as a laxative after 2 hours. Praziquantel is administered after fasting or after a light meal, so that the drug is optimal absorbed by the worm. The laxative is added in order to evacuate the worm as soon as possible, especially in cases when it is not sure if the worm is $T$. saginata, $T$. asiatica or T. solium. In case of taeniasis solium the possibility of eggs erupting from segments and then entering the stomach by retro-peristalsis should not be overlooked. The sooner the patient get rid of the worm the better. However, some authors give patients praziquantel after a meal and without laxative. It is not necessary to hospitalize the patient as only mild side effects are present such as headache or nausea.

\section{Cysticercosis}

In most cases of cysticercosis, especially neurocysticercosis and subcutaneous cysticercosis, at the present time the drug of choice is albendazole, one of the derivatives of imidazole. The drug is quickly absorbed, enhanced by fatty foods and possibly by bile salts. It is rapidly metabolized in the liver and may be in the intestine to change into albendazole sulfoxide, the compound with potent anthelmintic activity, which will then be distributed into various tissues. Albendazole is given, $15 \mathrm{mg} / \mathrm{kg} /$ body weight, during 8 days, as a single dose or divided into 2 doses. Especially, in case of neurocysticercosis the drug is accompanied by $50 \mathrm{mg}$ of prednisone, each morning during 8 days to prevent marked edema due to dying cysts. Steroids may affect levels of anthelmintics: it is increasing the plasma level of albendazole, however it decrease the level of praziquantel. Steroids may also relieve the headache occurring during the first days of the treatment. For existing seizures sodium phenytoin, $100 \mathrm{mg}, 2$ capsules, single dose during 8 days is an effective drug. As a second choice praziquantel can be used $50 \mathrm{mg} / \mathrm{kg} /$ day divided TID for $8-15$ days. Both drugs are cysticidal, decrease seizures for a longterm and diminish the number and size of intraparenchymal lesions. ${ }^{21}$ The majority of neurocysticercosis allows treatment at the outpatient clinic. The new drug schemes have become brief, cheap and generally safe. Hospitalization is needed for patients with a large number of cysts or with cysts in dangerous locations such as in the brainstem, the optic nerve, the ventricles etc. For the last mentioned cases immunosuppressive therapy e.g methotrexate or cyclophosphamide is needed ${ }^{2}$. In ocular cysticercosis drug therapy is contra-indicated because irreparable damage could be provoked. Extirpation of cysts is then recommended. In meningeal cysticercosis with vasculitis and chronic meningitis in which activated lymphocytes and immune mediators are dispersed throughout the nervous system by the cerebro-spinal fluid circulation the main treatment is with steroids during long term and ventricular shunting. ${ }^{5}$

Therefore nowadays the general rule is to treat patients with viable cysts using effective drugs except when cystocidal drugs are hazardous for a few catagories of patients.

Management of cysticercosis and also taeniasis in Indonesia is not always easy, especially in remote areas where health facilities are very limited, however with the availability of two highly effective cestocidal 
drugs, albendazole and praziquantel, adequate therapeutic schemes with the simultaneous use of symptomatic therapy can be properly conducted.

\section{REFERENCES}

1. Departemen Kesehatan R.I., Sub Dit Zoonosis, Direktorat Pemberantasan Penyakit Bersumber Binatang, Direktorat Jenderal PPM \& PL. Petunjuk pemberantasan taeniasis / sistiserkosis di Indonesia. 2003: 32 pg.

2. Depari AA. Hospes perantara alami Taenia saginata di Pulau Samosir, Sumatera Utara (The natural intermediate host of Taenia saginata at Pulau Samosir, Sumatera Utara). Maj Parasitol Ind 1997;10:59-65.

3. Margono SS, Wandra T, Suroso T, Ito A. Taeniasis and cysticercosis in Indonesia. In: Asian Parasitology. Taeniasis/cysticercosis and echinococcosis in Asia. The Federation of Asian Parasitologists. Series monograph 2004; 2: 115-34.

4. Lewis SL, Sotelo J. Case studies in neurocysticercosis. American Academy of Neurology. Philadelphia USA. 2001: 2BS.001-6.

5. Sotelo J. Treatment of neurocysticercosis. American Academy of Neurology. Philadelphia USA. 2001: 2BS.007-12.

6. Koesharjono C, Sri Sukartinah I, Suaedah, Windiyaingsih C, Panjaitan W, IM Suarnawa, Subandi. Praziquantel sebagai obat untuk pengobatan taeniasis (cacing pita). [Praziquantel for the treatment of taeniasis (tapeworms)] Maj Parasitol Ind, 1987;1:23-8.

7. Tierney, Jr. LM, McPhee SJ, Papadakis, MA. Current medical diagnosis and treatment. Lange Medical Books/McGraw-Hill, 2001:1455-6.

8. Hamid A, Nakaya K, Margono SS, Subahar R, Nakao M, Purba W, Ito A. Therapy for neurocysticercosis: comparison between albendazole and praziquantel in Wamena, lembah Baliem, Jayawijaya, Papua, Indonesia. The fourth Asian and Oceanian Epilepsy Congress (Poster Session), Karuizawa 2002
9. De Silva N, Guyatt H, Bundy D. Clinical use of anthelmintics. Medical Progress 1997: 43-8.

10. Strickland GT. Hunter's Tropical Medicine. $6^{\text {th }}$ Ed., WB Saunders CO. Philadelphia 1984 (cited by Koesharjono et al, 1987)

11. Clinton White, JrA. Neurocysticercosis: A major cause of neurological disease world wide. State of the art. Clinical article. Clinical Infectious Diseases, 1997;24:101-15.

12. Puri P, Grover AK. Medical management of orbital myocysticercosis: a pilot study. Eye, 1998:795-9 (cited by Sotelo, 2001).

13. Cruz M, Cruz I, Horon J. Albendazole vs praziquantel in the treatment of cerebral cysticercus: clinical evaluation. Trans Roy Soc Trop Med Hyg 1991;85:244-7 (cited by Sotelo, 2001).

14. Takayanagui OM, Jardim E. Therapy for neurocysticercosis. Comparison between albendazole and praziquantel. Arch Neurol 1992; 49: 290-4.

15. Sotelo J. Treatment of brain cysticercosis. Surg Neurol 1997;48:110-2 (cited by Sotelo, 2001).

16. Del Bruto $\mathrm{OH}$, Sotelo J. Albendazole therapy for subarachnoid and ventricular cysticercosis. Case report. J Neurosurg 1990;72:816-7 (cited by Sotelo, 2001).

17. Lozano-Elizondo D, Barbosa-Horta S. Tratamiento con albendazol de la cisticercosis intraocular. Rev Mex Oftalmol 1990;64:15-28 (cited by Sotelo, 2001).

18. Margono SS, Himawan S, Purnama TA, Subahar R, Hamid A, Ito A. Multiple cysticercus nodules in skin and brain in a woman from Bali, Indonesia. Med J Indones 2002;11:169-73.

19. Sotelo J, Jung H. Pharmacokinetic optimization of the treatment of neurocysticercosis. Clinical Pharmacokinetics 1998;34:503-15 (cited by Sotelo, 2001).

20. Ito A, Plancarte A, Ma L et al. Novel antigens for neurocysticercosis: a simple method for preparation and evaluation for serodiagnosis. Am J Trop Med Hyg 1998;59:291-4.

21. Neurocysticercosis. American Academy of Neurology, Philadelphia 2001:7FC.006-157. 